\title{
Presence of herpesvírus in diseased fishes
}

\author{
Fabíola de Souza $^{1 *}$, Marcia H. B. Catroxo ${ }^{2}$, Ana Maria Cristina R. P. F. Martins ${ }^{3}$, \\ Rodrigo Barbosa de Souza ${ }^{4}$, Christiane Alves de Oliveira ${ }^{5}$, Marcio Hipólito ${ }^{6}$ SP, Brazil
${ }^{3,6}$ Interinstitutional Laboratory of Aquaculture Health, Research and Development Center in Animal Health, Biological Institute, São Paulo, SP, Brazil
${ }^{4}$ Federal University of São Paulo State - UNIFESP, São Paulo, SP, Brazil \\ ${ }^{1,2,5}$ Electron Microscopy Laboratory, Research and Development Center in Animal Health, Biological Institute, São Paulo,
}

\begin{abstract}
Herpesviruses that infect fishes belong to the Herpesvirales order and Alloherpesvirus family. In these species, the different types of herpesvirus can cause tumors, adenocarcinoma and skin lesions. This study aims detect to presence of herpesvirus in fishes from commercial, recreation or experimental creations of the States of São Paulo and Minas Gerais, Brazil. Organ fragments and lesions of 53 fish species coming of mortality cases were forwarded at Biological Institute for examination by transmission electron microscopy by research of etiological agent. By transmission electron microscopy through negative staining technique, were observed herpes virus-like particles in 46 fishes and through embedding resin technique, in ultrathin sections were visualized herpes virus immature particles, measuring 90-110nm in diameter, located in the nuclei and complete particles measuring 160nm. In the histopathology technique, lesions associated with the virus as corpuscles inclusion, papillomas, and dermal lesions and in the gills were observed in 27 fishes. The evaluated techniques of TEM and the histopathology were effective for the rapid detection of herpesvirus in the examined samples.
\end{abstract}

Keywords — Disease, histopathology, transmission electron microscopy, herpesvirus.

\section{INTRODUCTION}

Aquaculture, in full development, is becoming more important as livestock activity, although it is still considered by many as an appendage of the fishing industry. Practiced in all Brazilian states, aquaculture mainly covers the following creations of fish, shrimp, frogs, shellfish, oysters and mussels and other aquatic crops such as growing algae are practiced on a smaller scale [1].

According to Toranzo et al. (2004) [2], infectious diseases caused by viruses can cause damage to the economic viability of aquaculture activities. These diseases occur mostly confined animals, and can develop serious infectious processes affecting the development of animals and even cause death.

Herpesviruses belong to Herpesvirales order, divided into three families, Alloherpesvirus, Herpesviridae and Malacoherpesvirus, encompassing viruses that occur in several animal species such as molluscs, fish, amphibians, reptiles, birds and mammals [3]. The Herpesviridae family keeps viruses of mammals, birds and reptiles, the Alloherpesviridae family includes fish and frogs viruses, and Malacoherpesviridae family contains the virus from bivalves [4].

The virus mainly affecting the early stages of fish life and therefore eggs, larvae and young fish are more susceptible. The infected eggs can produce larvae, newly hatched, with clinical signs of illness, while the infected adult fish may or may not present any symptoms [5]. Within the family of herpesviruses, can highlight herpesvirus papilloma of cyprinids [6], channel catfish herpesvirus and herpesvirus salmon [7].

The need for a more detailed and thorough knowledge of the damage caused by herpesviruses in aquaculture, especially in fish farming, has led us to this research. The pathological relationship between etiologic agents involving these animals is not well established, since in Brazil there is no survey of the pisces herpesviroses, and the reports are sporadic and opportunistic, depending on the shipment of samples to a diagnostic center. In this way, all studies in the area are important because the virus can remain latent in healthy animals or decimate entire flocks in a breeding, unfeasible a production. 
This study aimed to detect the presence of herpes virus in organs fragments of fishes from the states of São Paulo and Minas Gerais, using transmission electron microscopy techniques (negative staining and resin embedding) and associating viral presence with indicative lesions observed by optical microscopy, using histological technique hematoxylin-eosin (H\&E).

\section{MATERIAL AND METHOD}

\subsection{Ethics statement}

This study was approved by Animal Experimentation Research Ethics Committee Instituto Biológico (protocol 137/14).

\subsection{Experimental design}

The collection of material was performed from samples received for examination by the Laboratório Interinstitucional de Sanidade em Aquicultura and the Laboratório de Microscopia Eletrônica, Instituto Biológico, São Paulo, SP, Brazil. The samples were from comercial, recreation or experimental creations of the States of São Paulo and Minas Gerais, Brazil. Were utilized 202 organ fragments, such as liver, kidney, spleen, intestine, gills, heart, brain and skin lesions of 53 fish. The examined species were, 3 catfish (Bagre sp), 2 african sharptooth catfish (Clarias gariepinus), 3 cobia (Rachycentron canadum), 14 carp (Ciprinus carpio), 1 grouper (Epinephelus marginatus), 1 lenticulata pike cichlid (Crenicichlalenticulata), 3 pacu (Piaractus mesopotamicus), 1 mida cichlid (Cichlassoma citrinellum), 1 red piranha (Serrasalmus nateteri), 1 snookfish (Centropomus parallelus), 1 black pacu (Colossoma macropomum) and 22 tilapia (Oreochromis niloticus) from cases of diseases and mortalities.

\subsection{Negative staining technique (rapid preparation)}

In the negative staining the fragments of organs and skin lesions were suspended in phosphate buffer 0.1 M, pH 7.0. Drops of the obtained suspension were placed in contact with metallic copper grids with carbon stabilized supporting film of $0.5 \%$ collodium in amyl acetate. Next, the grids were drained with filter paper and negatively stained at $2 \%$ ammonium molybdate, pH $5.0[8,9,10]$.

\subsection{Resin embedding technique}

Thin slices the fragments of organs and skin lesions were fixed in $2.5 \%$ glutaraldehyde in $0.1 \mathrm{M}$, pH7.0 phosphate buffer and pos-fixed in $1 \%$ osmium tetroxide in the same buffer. After dehydration in cetonic series, the fragments were embedded in Spurr resin [11,12]. Ultrathin sections were cut on the LKB ultratome and mounted on copper grids. The sections were stained by combination of uranyl acetate and lead citrate [13,14].

\subsection{Routine histological technique}

Fragments of organs and skin lesions of 27 fish, were fixed in 10\% buffered formalin, dehydrated, diaphonized and embedded in paraffin. $4 \mu \mathrm{m}$ thick sections were performed and stained with hematoxylin (Harris) and eosin technique [15].

\section{RESUlts}

\subsection{Negative staining technique (rapid preparation)}

On transmission electron microscopy Philips EM 208, using the negative staining technique (rapid preparation) it was found enveloped (figure 1) and non-enveloped (figure 2), isometric, pleomorphic herpesvirus-like particles, measuring 120-200 nm of diameter in $46(86.8 \%)$ out of the 53 examined fish, from 202 samples of organs fragments. The positive species were, 3 catfish (Bagre sp), 2 african sharptooth catfish (Clarias gariepinus), 3 cobia (Rachycentron canadum), 14 carp (Ciprinus carpio), 1 grouper (Epinephelus marginatus), 1 lenticulata pike cichlid (Crenicichla lenticulata), 3 pacu (Piaractus mesopotamicus), 1 midas cichlid (Cichlassoma citrinellum), 1 red piranha (Serrasalmus nateteri), 1 snookfish (Centropomus parallelus), 1 black pacu (Colossoma macropomum) e 15 tilapias (Oreochromis niloticus). A total of 7 animals (13.21\%) (tilapias - O. niloticus) were negative for herpesvirus. 


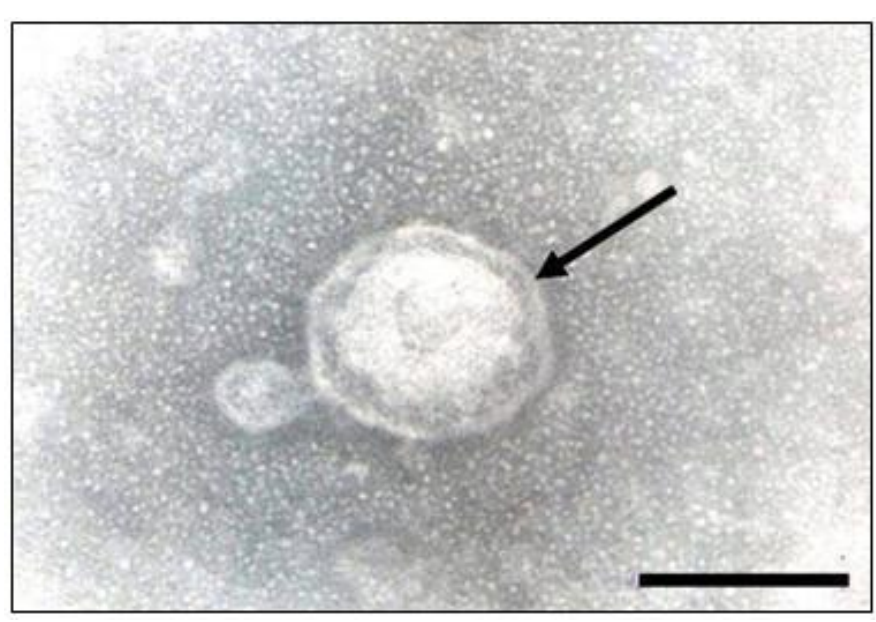

FIG. 1 - ELECTRON MICROGRAPH OF ENVELOPED HERPESVIRUS PARTICLE (ARROW) IN CARP LIVER FRAGMENT SUSPENSION. BAR: $140 \mathrm{~nm}$.

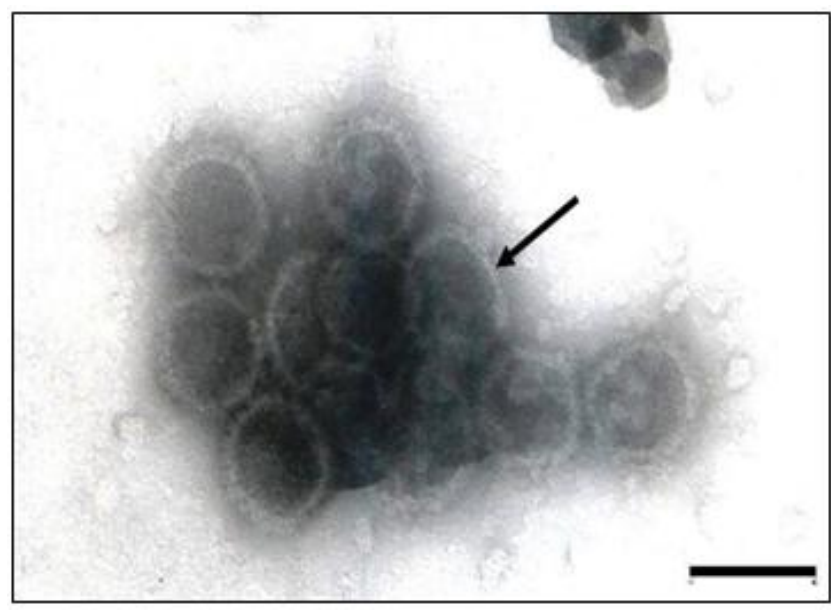

FIG. 2 - ELECTRON MICROGRAPH SHOWING VIRAL NUCLEOCAPSIDS (ARROW) IN CARP LIVER SUSPENSION. BAR: $120 \mathrm{~nm}$.

\subsection{Resin embedding technique}

All positive samples from liver, brain and skin by negative staining technique were subjected the resin embedding technique. In ultrathin sections was observed immature herpesvirus particles (figure 3), measuring 90-110 nm in diameter, located in the nucleus and complete particles measuring $160 \mathrm{~nm}$ in diameter. Extensive proliferation of the nuclear membrane producing complex finger-like extensions and amorphous inclusions located near the nucleus were visualized (figure 4).

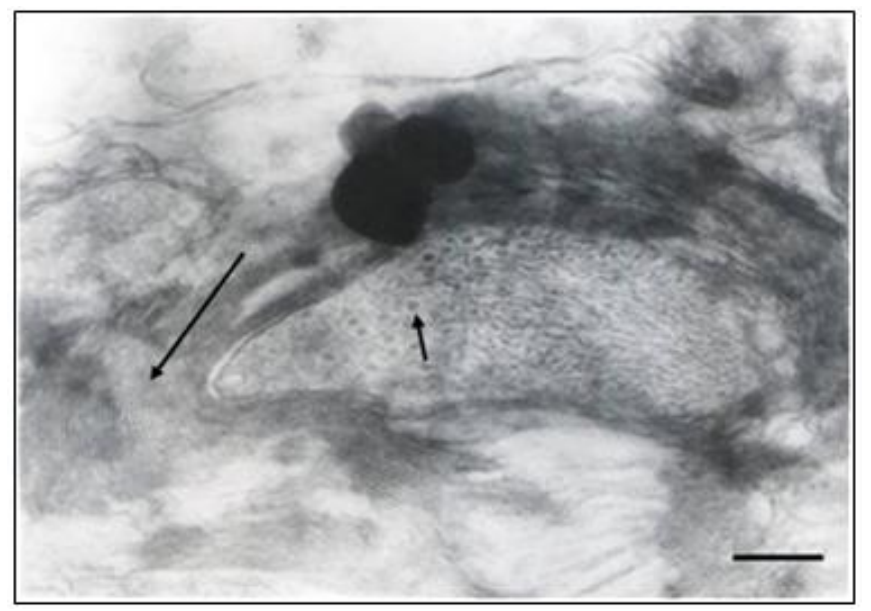

FIG. 3 - ELECTRON MICROGRAPH OF ULTRATHIN SECTIONS OF SNOOKFISHS BRAIN SHOWING THE PRESENCE OF INCOMPLETE HERPESVIRUS PARTICLE (LOWER ARROW) AND EXTENSIVE PROLIFERATION OF NUCLEAR MEMBRANE PRODUCING FINGER-LIKE EXTENSIONS (LARGE ARROW). BAR: $800 \mathrm{~nm}$.

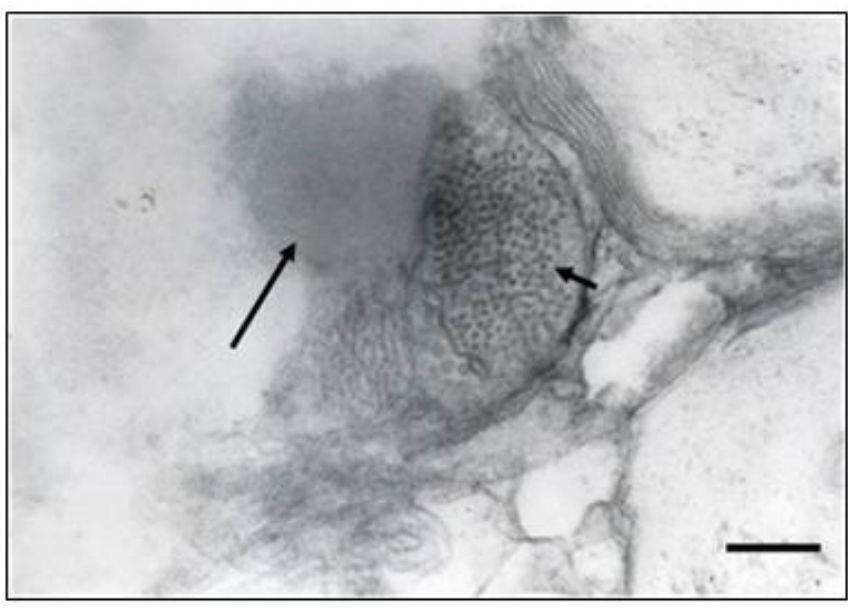

FIG. 4 - ELECTRON MICROGRAPH OF ULTRATHIN SECTIONS OF SNOOKFISH BRAIN INDICATING THE PRESENCE OF INCOMPLETE HERPESVIRUS PARTICLE (MINOR ARROW) AND AMORPHOUS INCLUSIONS LOCATED NEAR THE NUCLEUS (BIG ARROW). BAR: $800 \mathrm{~nm}$.

\subsection{Routine histological technique}

Positive samples by negative staining technique of 27 fish were examined by routine histological technique (H\&E). The examined species were, 13 carps, 8 tilapia, 2 african sharptooth catfish, 1 tambaqui, 1 red piranha, 1grouper and 1 midas cichlid. The observed lesions associated with the viral presence (figure5) are shown in Table 1. 


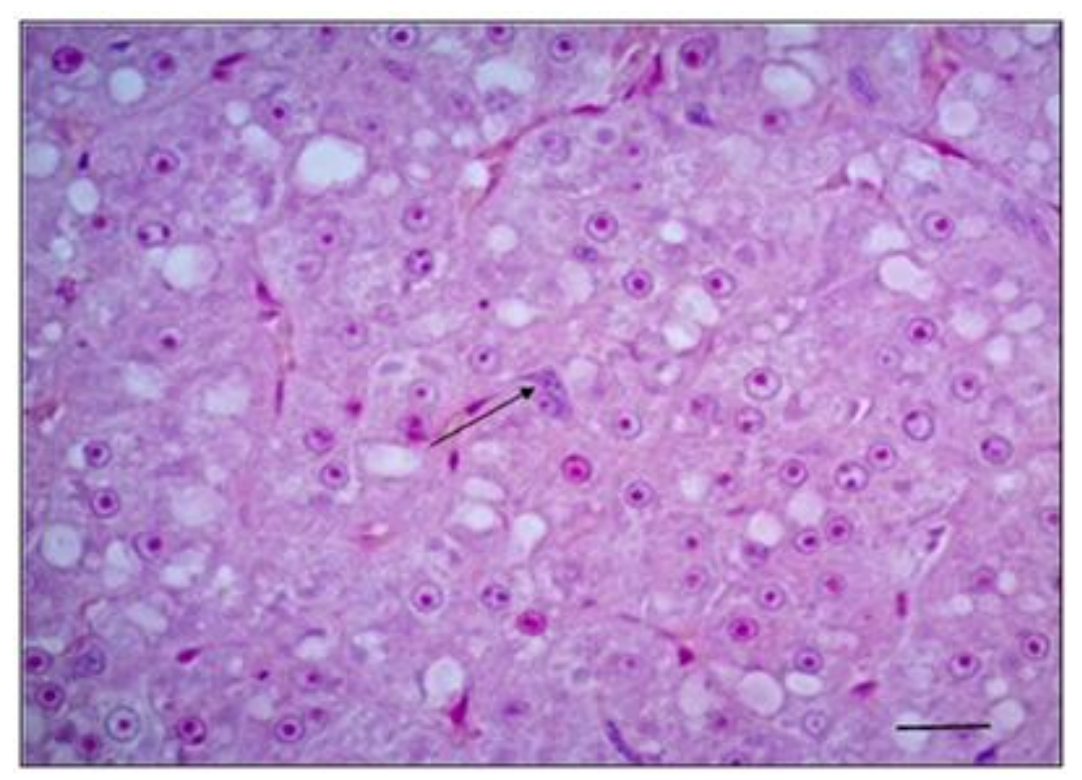

Fig. 5 - PHOTOMICROGRAPH OF HISTOLOGICAL SECTION OF AFRICAN SHARPTOOTH CATFISH LIVER, INDICATING HERPESVIRUS BASOPHILIC NUCLEAR INCLUSION (ARROW). HE STAINING. BAR: $20 \mu \mathrm{m}$.

TABLE 1

MAIN HISTOPATHOLOGICAL LESIONS OBSERVED IN FISH AND NUMBER OF AFFECTED ANIMALS / ANALYZED ANIMALS.

\begin{tabular}{|c|c|c|c|c|c|c|c|c|}
\hline & Live & Kidney & Spleen & Hepatopancreas & Gill & Pancreas & Skin & CNS \\
\hline Foamy areas & $0 / 16$ & $0 / 15$ & $0 / 17$ & $0 / 9$ & $0 / 16$ & $6 / 9$ & $0 / 7$ & $0 / 3$ \\
\hline Dystrophic calcification & $0 / 16$ & $7 / 15$ & $0 / 17$ & $0 / 9$ & $0 / 16$ & $0 / 9$ & $0 / 7$ & $0 / 3$ \\
\hline Corpuscles inclusion & $3 / 16$ & $1 / 15$ & $0 / 17$ & $2 / 9$ & $0 / 16$ & $0 / 9$ & $3 / 7$ & $1 / 3$ \\
\hline Fibrin exudates & $0 / 16$ & $6 / 15$ & $4 / 17$ & $0 / 9$ & $0 / 16$ & $0 / 9$ & $0 / 7$ & $1 / 3$ \\
\hline $\begin{array}{c}\text { Secondary fusion of } \\
\text { primary lamellae }\end{array}$ & $0 / 16$ & $0 / 15$ & $0 / 17$ & $0 / 9$ & $6 / 16$ & $0 / 9$ & $0 / 7$ & $0 / 3$ \\
\hline Bleeding & $2 / 16$ & $8 / 15$ & $15 / 17$ & $0 / 9$ & $0 / 16$ & $0 / 9$ & $2 / 7$ & $1 / 3$ \\
\hline $\begin{array}{c}\text { Hyperplasia mononuclear } \\
\text { cells }\end{array}$ & $0 / 16$ & $0 / 15$ & $10 / 17$ & $0 / 9$ & $0 / 16$ & $0 / 9$ & $0 / 7$ & $0 / 3$ \\
\hline Epithelial hyperplasia & $0 / 16$ & $0 / 15$ & $0 / 17$ & $0 / 9$ & $0 / 16$ & $0 / 9$ & $4 / 7$ & $0 / 3$ \\
\hline $\begin{array}{c}\text { Lesions suggestive of } \\
\text { papilloma }\end{array}$ & $0 / 16$ & $0 / 15$ & $0 / 17$ & $0 / 9$ & $0 / 16$ & $0 / 9$ & $3 / 7$ & $0 / 3$ \\
\hline Melanomacrophages & $3 / 16$ & $6 / 15$ & $13 / 17$ & $0 / 9$ & $0 / 16$ & $7 / 9$ & $3 / 7$ & $1 / 3$ \\
\hline Necrosis & $2 / 16$ & $4 / 15$ & $2 / 17$ & $2 / 9$ & $1 / 16$ & $1 / 9$ & $4 / 7$ & $1 / 3$ \\
\hline Nephrosis & $0 / 16$ & $3 / 15$ & $0 / 17$ & $0 / 9$ & $0 / 16$ & $0 / 9$ & $0 / 7$ & $0 / 3$ \\
\hline $\begin{array}{c}\text { Cytoplasmic rarefaction } \\
\text { Inflammatory reaction }\end{array}$ & $12 / 16$ & $0 / 15$ & $0 / 17$ & $5 / 9$ & $0 / 16$ & $0 / 9$ & $0 / 7$ & $0 / 3$ \\
\hline Congestion of blood vessels & $8 / 16$ & $0 / 15$ & $0 / 17$ & $0 / 9$ & $7 / 16$ & $3 / 9$ & $0 / 7$ & $3 / 3$ \\
\hline
\end{tabular}

\section{DISCUSSION}

In this study, 202 samples of organ fragments from 53 fish were processed by the negative staining technique for transmission electron microscopy. Of these 53 fish, 46 (86.8\%) were positive for herpes virus. 
Studies around the world show a mortality rate of 80 to $100 \%$ in creations of carps infected by both CyHV -2 and CyHV-3 $[16,17,18,19,20]$ as well by IcHV-1 that infects channel catfish [21], the 3 types of fish herpesvirus most frequent. Not yet know here in Brazil, which are the types of herpes viruses that are present in fish.

Particles with morphology similar to herpesvirus, pleomorphic, isometric, some enveloped, measuring between 120 to 200 $\mathrm{nm}$ in diameter, were visualized in all samples of organ fragments from the 46 positive fish of our study. These morphological features are also described by other authors in studies with herpesvirus made in tilapia larvae [22], in Osmerus eperlanus [23] and in Ictalurus nebulosu [24].

In ultrathin sections of brain, liver and skin of the positive fish of our study, were observed immature and complete herpesvirus particles, located in the nucleus, aspects also seen in tumor cells of Osmerus eperlanus, where herpesvirus particles were viewed in the cytoplasm [23].

The resin embedding technique has also been applied to study ultrastructural aspects of herpesvirus into cells infected by CyHV-3 [17,25,26,27,28], of the Koi herpesvirus (KHV) infecting carp (Cyprinus carpio) [29] and of the CCV (channel catfish virus) in a kind of catfish (Ictalurus nebulosus). 4 From this technique herpesvirus particles were visualized in all stages of development in the nucleus, granular bodies containing virus particles, lamellar structures and altered nuclear membrane, and numerous viral particles in the cytoplasm [24].

This technique applied in the spleen and kidney lesions, carried out in goldfish by Lovy and Friend (2014) [30] confirmed the presence of the herpesvirus in the nucleus and cytoplasm of necrotic cells. The authors also observed that the nucleus had marginalized chromatin.

We found the incomplete particles measured between 90 and $110 \mathrm{~nm}$, and the complete particles measured on average 160 nm in diameter.

These findings were consistent with other ultrastructural studies that reported who the nucleocapsids of the CyHV-1, CyHV2 and CyHV-3, measured 100 a $113 \mathrm{~nm}$ and the mature enveloped particles, measured $190 \mathrm{~nm}$ to $230 \mathrm{~nm}$ in diameter $[31,32,33,34,35]$, located in the cytoplasm and extracellular space [33].

In fish of our study, the clinical signs and symptoms most commonly observed were incoordination, lethargy, sudden death, skin lesions (fin and mouth), liver nodules and liver and intestinal disorders.

These symptoms and signs have also been reported in fish infected by CyHV-2, CyHV-3 and IcHV, such as, Carassius auratus [33,19], Cyprinus carpio [17,36], Ictalurus punctatus [37,24] and Oreochromis aureus [22].

We find lesions like-papillomas in skin of 3 tilapia.

Lesions petechial or papillomatous around the body, mouth, cornea, kidneys and jaw have been reported in fish infected with herpesvirus Salmon, such as, Oncorhynchus keta [38,39], Cyprinus carpio [40], Oncorhynchus kisutch, Oncorhynchus keta, Oncorhynchus masou and Salmo gairdneri (Yoshimizu et al., 1987) [41]. Papilloma like lesions were also observed in CyHV-1 infection in the fish species [42,43,31]. In Cyprinus carpio infected by CyHV-3, the most commonly encountered lesions were located in the gills $[17,44,45,46,29]$.

Regarding histopathology, in 5 carp and in 1 african sharptooth catfish of our study we found gill lesions, such as fusion the primary and secondary blades.

Histopathological examinations performed by Lovy and Friend (2014) [30] in goldfish (Carassius auratus), also showed the presence of fusion of gill filaments in all fish positive for herpesvirus examined in their study. This finding was attributed to epithelial hyperplasia, the infiltration of eosinophilic cells and occasionally diffuse necrosis. Pikarsky et al. (2004) [46] also included as branchial arch lesions suggestive of herpesvirus, subepithelial increase inflammation and congestion of blood vessels in carp. These lesions also were found by us in grouper, carp and tilapia.

In kidney of catfish, carp and tilapia were observed focuses with hemorrhage and the light of many tubules was visualized fibrinoid and hyaline material, necrotic areas, and the presence of melanomacrophages. It was observed particulary marked mononuclear glomerulonephritis as well as dystrophic calcification (calcium deposition).

Plumb et al. (1974) [47] and Wolf et al. (1972) [48] observed in your studies conducted in catfish (Ictalurus punctatus), the presence of extensive edema, inflammation and necrosis of the renal tubules. Pikarsky et al. (2004) [46] found blood vessels 
congested in carp infected by herpesvirus, while Lovy and Friend (2014) [30] verified the presence of necrosis and dilated blood vessels in goldfish.

In tilapia (O. niloticus) and catfish (Bagre $s p$ ) hepatic tissue, in general, showed cytoplasmic rarefaction (mineral protein deficiency), numerous melanomacrophages, hepatitis focal monolimphocytary and necrosis.

Plumb et al. (1974) [47] and Wolf et al. (1972) [48] cite the focal necrosis, hemorrhage and edema as the main lesions found in the liver of animals infected with herpesvirus of Ictaluridae (IcHV1).

In the spleen of catfish, carp and tilapia, the most significant lesions found were hemorrhagic areas, presence of melanomacrophages hyperplasia of mononuclear cells, and necrosis.

These findings were corroborated by Lovy and Friend (2014) [30] in goldfish. Moreover, Plumb et al. (1974) [47] and Wolf et al. (1972) [48] found in their studies apart of changes observed in our work, congested blood vessels.

In our study we found the presence of inclusion bodies in skin of 2 tilapia and of 1 catfish, in hepatopancreas of 1 tilapia and of 1 carp, in liver of 1 catfish and 2 carps, in kidney of 1 tilapia and in the SNC of 1 midas cichlid.

Gibson-Kueh et al. (2012) [49] also found these inclusion bodies in the spleen, kidney, liver and heart in their studies in giant perch (Lates calcarifer) infected with herpesvirus.

According to Yamamoto et al. (1983) [50] and Elias et al. (2004) [51], the presence of inclusion bodies basophilic is the major histopathologic alteration characteristic of the presence of herpesvirus.

\section{CONCLUSION}

From these findings it was concluded that electron microscopy techniques used in this study were effective in diagnosing the presence of herpesvirus, allowing the visualization of agent, and should be spread widely.

Routine histopathological technique was also effective in the visualization of lesions suggestive of the viral agent, as the presence of inclusion bodies. Moreover, enabled to perform the analysis of the animals overall condition, indicating that the quality of creation can make it susceptible to infection by herpesvirus. Histopathology and electron microscopy tests must be complementary.

We cannot here say that the disease, followed by mortality, are directly caused by herpesvirus, however, serious conditions predisposing to poor water quality, unsuitable managements, high density and poor nutritional quality must have contributed to viral replication. The viral presence, of course, contributed to the worsening of the picture, intensifying clinical symptoms followed of mortality. Studies to assess what are the fish herpesvirus subtypes that are circulating in our country and its real impact on mortality should be conducted.

\section{ACKNOWLEDGEMENTS}

The research was supported by Coordenação de Aperfeiçoamento de Pessoal de Nível Superior (CAPES).

\section{REFERENCES}

[1] Scorvo-Filho, J.D. Panorama da aquicultura nacional. In: Textos técnicos - Instituto de Pesca. Disponível em: ftp://ftp.sp.gov.br/ftppesca/panorama_aquicultura.pdf Acesso em: 22 de agosto de 2013.

[2] Toranzo AE, Barja JL, Dopazo CP and Romalde JL. 2004. Enfermidades bacterianas y víricas de peces marinos. In: Ranazani-Paiva, MJT, Takemoto RM, Lizama MLA. 2004. Sanidade de Organismos Aquáticos. Editora Varela, São Paulo. p.3-49.

[3] International Committee on Taxonomy of Viruses (ICTV). 2013. Virology Division - IUMS. Disponível em: http://ictvonline.org/virusTaxonomy.asp. Acesso em: 12 de dezembro de 2013.

[4] Davison AJ, Eberle R, Ehlers B, Hayward GS, Mcgeoch DJ, Minson AC, Pellett PE, Roizman B, Studdert MJ and Thiry E. 2009. The order Herpesvirales. Arch. Virol., v.154, n. 1, p. 171-177.

[5] Martins AMCRPF, Hipolito M and Catroxo M.B. 2011. A importância da piscicultura e algumas doenças virais e bacterianas písceas. Comunicado técnico, Instituto Biológico, Centro de pesquisa e desenvolvimento sanidade animal, n.156. Disponível em: http://www.biologico.sp.gov.br/artigos_ok.php?id_artigo=156. Acesso em: 03 de fevereiro de 2014.

[6] Schubert, GH. 1966. The infective agent in carp pox. Bulletin Office of International Epizootics, p.1011-1022.

[7] Wolf K. 1983. Biology and properties of fish and reptilian herpesviruses. In: The Herpersviruses. v.2 ( Roizman, b., ed.). Plenum Press: New York. p.319-366. 
[8] Brenner S and Horne RW. 1959. A negative staining method for high resolution electron microscopy of viruses. Biochim. Biophys. Acta., 34:103-10.

[9] Hayat MA and Miller SE. 1990. Negative Staining. McGrawHill Publ. Company, p.235.

[10] Madeley CR. 1997. Origins of electron microscopy and virus diagnosis. J. Clin. Pathol., 50(6):454-6.

[11] Gonzalez-Santander R. 1969. Técnicas de microscopia electrónica en biología. Madrid, Ed. Aguilar, p.666.

[12] Luft JH. 1961. Improvements in an epoxy resin embedding methods. J. Biophys. Biochem. Cytol., 9:409-14.

[13] Watson, M. L. 1958. Staining of tissue sections for electron microscopy with heavy metals. J. Biophyis. Biochem. Cytol., 4:475-8.

[14] Reynolds ES. 1963. The use of lead citrate at high pH as an electron-opaque stain in electron microscopy. J. Cell. Biol., 17:208-12.

[15] Michalany J. 1980. Técnica histológica em anatomia patológica. Editora Pedagógica e Universitária Ltda., São Paulo, 277p.

[16] Bretzinger A, Fischer-Scherl T, Oumouma R, Hoffmann R and Truyen U. 1999. Mass mortalities in koi, Cyprinus carpio, associated with gill and skin disease. Bull. Eur. Ass. Fish Pathol., v.19, p.182-185.

[17] Hedrick RP, Gilad O, Yun S, Spangenberg JV, Marty GD, Nordhausen RW, Kebus MJ, Bercovier H, Eldar A (2000) A herpesvirus associated with mass mortality of juvenile and adult koi, a strain of common carp. J Aquat Anim Health 12:44-57.

[18] Hoffmann R. 2000. Eine Koiseuche bedroht die Karpfenteichwirtschaft. Fischer und Teichwirt 11: 432.

[19] Goodwin AE, Merry GE and Sadler J. 2006. Detection of the herpesviral hematopoietic necrosis disease agent (cyprinid herpesvirus 2) in moribund and healthy goldfish: Validation of a quantitative PCR diagnostic method. Dis. Aquat. Org., v.69, p.137-143.

[20] Garver KA, Al-Hussinee L, Hawley LM, Schroeder T, Edes S, Lepage V, Contador E, Russell S, Lord S, Stevenson RM, Souter B, Wright E and Lumsden JS. 2010. Mass mortality associated with koi herpesvirus in wild common carp in Canada. J. Wildl Dis., v.46, n.4, p.1242-1251.

[21] Plumb JA. 1973. Effects of temperature on mortality of fingerling channel catfish (ictalurus punctatus) experimentally infected with channel catfish virus. J. Fish. Res. Board Can., v.30, p.568-570.

[22] Shlapobersky M, Sinyakov MS, Katzenellenbogen M, Sarid R, Don J and Avtalion RR. 2010. Viral encephalitis of tilapia larvae: Primary characterization of a novel herpes-like virus. Virol., v.399, n.239-247.

[23] Anders K. 1988. Biology of tumor-and tumor-like diseases of fish from the lower. Elber River. Moller Publication, Kiel (In German).

[24] Wolf K. and Darlington RW. 1971. Channel Catfish Virus: a New Herpesvirus of Ictalurid Fish. J. Virol., v.8, n.4, p. $525-533$.

[25] Hutoran M, Ronen A, Perelberg A, Ilouze M, Dishon A, Bejerano I, Chen N and Kotler M. 2005. Description of an as yet unclassified DNA virus from diseased cyprinus carpio species. J. Virol., v. 79, p.1983-1991.

[26] Miwa S, Ito T and Sano, M. 2007. Morphogenesis of koi herpesvirus observed by electron microscopy. J. Fish Dis., v. 30, p.715-722.

[27] Mettenleiter TC, Klupp BG and Granzow H. 2009. Herpesvirus assembly: An update. Virus Res.,v.143, p.222-234.

[28] Raj VS, Fournier G, Rakus K, Ronsmans M, Ouyang P, Michel B, Delforges C, Costes B, Farnir F, Leroy B, Wattiez R, Melard C, Mast J, Lieffrig F and Vanderplasschen A. 2011. Skin mucus of Cyprinus carpio inhibits cyprinid herpesvirus 3 binding to epidermal cells. Vet Res., v.42, p.9.

[29] Miyazaki T, Kuzuya Y, Yasumoto S, Yasuda M and Kobayashi T. 2008. Histopathological and ultrastructural features of koi herpesvirus (KHV) -infected carp Cyprinus carpio, and the morphology and morphogenesis of KHV. Dis. Aquat. Org., v.80, n.1-11.

[30] Lovy J and Friend SE. 2014. Cyprinid herpesvirus-2 causing mass mortality in goldfish: applying electron microscopy to histological samples for diagnostic virology. Dis Aquat Org., v.108, p.1-9.

[31] Sano T, Fukuda H, Furukawa M, Hosoya H and Moriya Y. 1985b. A herpesvirus isolated from carpa papiloma in Japan. In: ELLIS, A.E. ed. Fish and shellfish pathology. Academic Press, London, p.307-311.

[32] Hedrick RP, Groff JM, Mcdowell TS and Wingfield WH. 1990. An iridovirus from the integument of white sturgeon. Dis. Aquat. Org., v. 8, n.39-44.

[33] Jung SJ and Miyazaki T. 1995. Herpesviral haematopoietic necrosis of goldfish, Carassius auratus (1). J. Fish Dis., v.18, p.211-220.

[34] Hedrick R.P., Gilad O., Yun S.C., McDowell T.S., Waltzek T.B., Kelley G.O., Adkison M.A. (2004): Initial isolation and characterization of a herpes-like virus (KHV) from koi. In: Report of International Workshop on Koi Herpesvirus, 12-13 February 2004, London, 6-7. [www. defra.gov.uk/science/Publications/Default.asp].

[35] Jeffery KR, Bateman K, Bayley A, Feist SW, Hulland J, Longshaw C, Stone D, Woolford G and Way K. 2007. Isolation of a cyprinid herpesvirus (CyHV-2) from goldfish Carassius auratus (L.), in the UK. J Fish Dis 30: 649-656.

[36] Davidovich M, Dishon A, Ilouze M and Kotler M. 2007. Susceptibility of cyprinid cultured cells to cyprinid herpesvirus 3. Arch. Virol., v.152, p.1541-1546.

[37] Fijan NN, Welborn TLJ and Naftel JP. 1970. An Acute Viral Disease of Channel Catfish. Technical bulletin No. 43; U. S. Fish and Wildlife Service: Washington, D.C.

[38] Kimura T, Yoshimizu M and Tanaka M. 1981. Fish Viroses: Tumor induction in Oncorhynchus keta by the herpesvirus. In: Dawe CJ, Harshbarger JC, Kondo S, Sugimura T and Takayama S. Eds. Phylogenetic approaches to cancer. Japanese Scientific Society Press, Tokyo, p.59-68.

[39] Kimura, T.; Suzuki, S.; Yoshimizu, M. 1983. In vivo antiviral effect of 9- (2-hydroxyethoxymethyl) guanine on experimental infection of chum salmon (Oncorhynchus keta) fry with Oncorhynchus masou virus (OMV). Res., v.3, p.103-108.

[40] Sano, T.; Fukuda, H.; Okamoto, N.; Kaneto, F. Yamane tumor virus: lethality and oncogenicity. Bull. Jap. Soc. Scient. Fish., v.49, p.1159-1163, 1983.

[41] Yoshimizu M, Tanaka M and Kimura T. 1987. Oncorhynchus masou vírus (OMV): Incidence of tumor development among experimentally infected representative salmonid species. Fish Pathol., v.22, p.7-10. 
[42] Schubert GH. 1964. Elektronen Mikroskopische Unterschungen Zur Pockenkrankheit Des Karpfens. Z Naturforsch., V.19b, P.675682.

[43] Sano T, Fukuda H and Furukawa M. 1985a. Herpesvirus cyprini: Biological and ancogenic properties. Fish Pathol., v. 20, p.381-388.

[44] Perelberg A, Smirnov M, Hutoran M, Diamant, Bejerano Y and Kotler M. 2003. Epidemiological description of a new viral disease afflicting cultured Cyprinus carpio in Israel. Isr J Aquacult Bamidgeh 55:5-12

[45] Ronen A, Perelberg A, Abramowitz J, Hutoran M, Tinman S, Bejerano I, Steinitz M and Kotler M. 2003. Efficient vaccine against the virus causing a lethal disease in cultured cyprinus carpio. Vaccine, v.21, p.4677-4684.

[46] Pikarsky E, Ronen A, Abramowitz J, Levavi-Sivan B, Hutoran M, Shapira Y, Steinitz M, Perelberg A, Soffer D and Kotler M. 2004. Pathogenesis of acute viral disease induced in fish by carp interstitial nephritis and gill necrosis virus. J. Virol., v.78, p.9544-9551.

[47] Plumb JA, Gaines JL, Mora EC and Bradley GG. 1974. Histopathology and electron microscopy of channel catfish virus in infected channel catfish, ictalurus punctatus (rafinesque). J. Fish. Biol., v., 6, p.661-664.

[48] Wolf. K., Herman, R.L., Carlson, C.P., 1972. Fish viruses: histopathologic changes associated with experimental channel catfish virus disease. J. Fish Res. Board Can. 29, 149-150.

[49] Gibson-Kueh S, Chee D, Chen J, Wang YH, Tay S, Leong LN, Ng ML, Jones JB, Nicholls PK and Ferguson HW. 2012. The pathology of 'scale drop syndrome' in Asian seabass, Lates calcarifer Bloch, a first description. J. Dis., v.35, p.19-27.

[50] Yamamoto T, Kelly RK and Nielsen O. 1983. Epidermal hyperplasias of Northern Pike (Esox lucius) associated with herpesvirus and c-type particles. Arch. Virol., v. 79, p.255-272.

[51] Elias F. Schild AL and Riet-Correa F. 2004. Meningoencefalite e encefalomalacia por herpesvírus bovino-5: distribuição das lesões no sistema nervoso central de bovinos naturalmente infectados. Pesq. Vet. Bras, v.24, p.123-131. 